\title{
Factors affecting the herbage iodine content
}

\section{J. Hartmans}

Institute for Biological and Chemical Research on Field Crops and Herbage (IBS), Wageningen, the Netherlands ${ }^{1}$

Accepted: 29 July 1974

\section{Summary}

Some factors related to intensification of pasture use were studied in field and pot experiments in their effect on herbage iodine content.

Nitrogen dressings somewhat increased iodine uptake in the harvested crop, but iodine concentration in the herbage was considerably decreased by the diluting effect of the highly increased dry matter yields. Dressings with other commercial fertilizers, not resulting in higher yields, did not consistently affect the herbage iodine content.

Dicotyledonous species occurring in pastures had up to 13 times higher iodine contents than grasses. Iodine content of grass species varied over a two-fold range; in varieties of the same species variation was smaller. Contrary to earlier New Zealand data good quality grasses were lower in iodine content than medium-value and inferior grasses. This effect may have been caused by continued breeding for maximum crop yield in the former species.

Small iodine dressings were less efficient in terms of percentage return in the harvested crop than higher doses, residual effects in later cuts always being very small. The efficiency of iodine dressings depended on soil type and there was a tendency of efficiency being lowest on soils with lowest natural iodine content.

\section{Introduction}

Relatively little information is available on factors affecting the iodine content of pasture plants. This may be mainly due to the lack of a sufficiently quick and sensitive method to analyse the traces of iodine in plant material.

Butler \& Johnson (1957) and Johnson \& Butler (1957) reported more than 20-fold differences in iodine contents between New Zealand pasture species. The highest contents were found in perennial ryegrass (Lolium perenne), Italian ryegrass (Lolium multiflorum) and white clover (Trifolium repens), the lowest in Yorkshire fog (Holcus lanatus), Poa annua, Poa trivialis and cocksfoot C23 strain (Dactylis glomerata). Red clover (Trifolium pratense), subterranean clover (Trifolium subterraneum) and short rotation ryegrass (Lolium perenne $\times$ multiflorum) were intermediate. The latter species, obtained by selection after hybridization, contained only 20 to $40 \%$ of the iodine concentration in the original species. In crossing experiments with Lolium perenne varieties Butler \& Glenday (1962) found high heritabilities for leaf iodine

1 Present address: National Council for Agricultural Research (NRLO-TNO), c/o P.O. Box 14, Wageningen, the Netherlands. 
content. As a rule the plant species was more important in New Zealand pastures than soil type or season (Johnson \& Butler, 1957).

Large species differences in iodine content were also found by Alderman \& Jones (1967). In some cases species differences were subordinate to varietal differences. Different from Butler's findings, the Loliums and fescues (Festuca pratensis and F. arundinacea) had the lowest and cocksfoot and timothy (Phleum pratense) the highest iodine content. A seasonal effect caused high iodine contents in early spring and in autumn, and low contents in summer. They also found a marked depressive effect of nitrogen fertilizer on the herbage iodine content.

Lehr (1961) found marked differences in herbage iodine content between soil types in the Netherlands. Highest contents were found on sea silt and peat soil, and lowest on sand and river clay. During the growing season a progressive increase in iodine content of herbage was observed.

The present paper reports the effect of some factors related to intensification of pasture use on the herbage iodine content, viz level and type of various $N, K, P$ and $\mathrm{Ca}$ fertilizers, botanical composition, single and split iodine dressings, and the effect of three soil types.

\section{Material and methods}

\section{Pot experiment}

Perennial ryegrass was grown in mineral-sand eulture in pots of 1.25 litres dressed with $\mathrm{KI}$ at $0,10,20,40,80,160$ and $200 \mu \mathrm{mol} /$ pot. Growth was supported by adding daily $10 \mathrm{ml}$ half-strength Hoagland type solution and water to compensate transpiratory losses ( $+\mathrm{N}$ series). A parallel series of pots received Hoagland solution during the first 3 days after each cutting; from then the supply of $\mathbf{N}$ was discontinued by substitution of sulphate for nitrate in the nutrient solution ( $-\mathrm{N}$ series).

At 20-day intervals 3 successive cuts were harvested and analysed for dry weight and iodine. Cut 3 was analysed only partially, the data confirm those of Cut 2 .

\section{Field experiments}

1. On a sandy soil (experimental farm 'Droevendaal' at Wageningen) $0,20,40,80$, 120 and $160 \mathrm{~kg} \mathrm{~N}$ per ha per cut were applied as ammonium nitrate limestone to a perennial ryegrass dominant pasture with very few herbs at two iodine levels, viz 0 and $2.68 \mathrm{~kg} \mathrm{KI}(=2.05 \mathrm{~kg} \mathrm{I})$ per ha applied at the beginning. Four successive cuts were harvested at $3500 \mathrm{~kg}$ DM per ha on the high $\mathrm{N}$ plots. The yield per plot was weighed, the few herbs removed from the samples and analysed for iodine.

2. On the same sandy soil the effect of different types of commercial $\mathbf{N}, \mathbf{P}, \mathbf{K}$ and Ca fertilizers on iodine content of the herbage was studied at two iodine levels, viz 0 and $2.50 \mathrm{~kg} \mathrm{KI}(=1.91 \mathrm{~kg} \mathrm{I})$ per ha applied at the beginning of the experiment. The plots received $80 \mathrm{~kg} \mathrm{~N}$ per ha per cut as ammonium nitrate limestone, except those receiving another form of $\mathrm{N}$. Two successive cuts were harvested and treated as in Field Exp. 1.

3. The effect on herbage iodine content of split dressings of $0,0.125,0.25,0.50$ and $1.00 \mathrm{~kg} \mathrm{KI}$ per ha per cut was compared to the effect of a single dressing in spring of 
$2.50 \mathrm{~kg} \mathrm{KI}$ per ha on three soil types, viz sand, river clay and peat; the highest split dressing was omitted on the sandy soil. $\mathrm{N}$ was dressed at $80 \mathrm{~kg}$ per ha per cut as ammonium nitrate limestone. Harvests were performed as in Field Exp. 1; only Cuts 1,2 and 5 were analysed.

4. Samples of several species and varieties of grasses and legumes were obtained from a variety testing experimental field of the Institute for Research on Varieties of Field Crops (IVRO); Cuts 1 and 2 were analysed for iodine. In addition, of a number of pastures, rich in herbs, grass and a number of dicotyledons were analysed separately for iodine in order to compare their iodine content under the same growing conditions.

\section{lodine determination}

The method of Sandell \& Kolthoff (1937), as modified by Barker et al. (1951), Binnerts (1956) and Foss et al. (1960), was used. After dry ashing under alkaline conditions the iodine concentration was measured based on the catalytic action of iodine on the reduction of ceric ion by arsenious ion.

The samples were dried at $70^{\circ} \mathrm{C}$; drying under alkaline conditions was not considered necessary. $500 \mathrm{mg}$ of ground sample were weighed into $130 \times 22 \mathrm{~mm}$ Pyrex tubes, $1 \mathrm{ml}$ of a solution of $20 \mathrm{~g} \mathrm{NaOH}$ and $10 \mathrm{~g} \mathrm{KNO}_{3}$ per litre water was added. After drying at $95^{\circ} \mathrm{C}$ the contents were incinerated during 30 minutes at $250{ }^{\circ} \mathrm{C}$, followed by 30 minutes at $400{ }^{\circ} \mathrm{C}$ and 4 hours at $550^{\circ} \mathrm{C}$. After cooling $1 \mathrm{ml}$ of the $\mathrm{NaOH}$ solution was added, the contents of the tubes were mixed, dried and heated during 6 hours at $550{ }^{\circ} \mathrm{C}$ to obtain a white ash.

As the molar extinction coefficient of CeIV at $320 \mathrm{~nm}$ is ten times higher than at $420 \mathrm{~nm}$, the former wavelength was used with corresponding lower CeIV and AsIII concentration in the measuring solution.

\section{Results}

\section{Yield effects of iodine dressings}

In the pot experiment application of iodine reduces the yield of dry matter by about $20 \%$ (Fig. 1a). This depressive effect is absent in the field experiments and in a preliminary pot experiment.

\section{Effect of iodine dressing on iodine content and uptake of herbage}

First cut after dressing. The pot experiment shows an almost linear relationship between iodine dressing and iodine content in both the $+\mathrm{N}$ and the $-\mathrm{N}$ series, though at a different level (Fig. 1c). Since data are presented on a logarithmic scale the ' 0 ' iodine treatment is plotted along the abcis according to the observed relationship.

In Field Exp. 3 the relationship is less simple (Fig. 2). Though in some cases there is a considerable scattering between replications, it appears from Cut 1 that the two lower iodine doses have no (Exp. 3a and 3b) or very little effect (Exp. 3c) on the herbage iodine content. Only doses higher than $0.25 \mathrm{~kg} \mathrm{KI}$ per ha show a definite increase. The same is found in the subsequent cuts, be it that the iodine levels, ineffective in increasing the iodine concentration, vary between experiments and cuts. The efficiency of the effective part of a dose, reflected in the slopes of the right-hand part of the lines, 

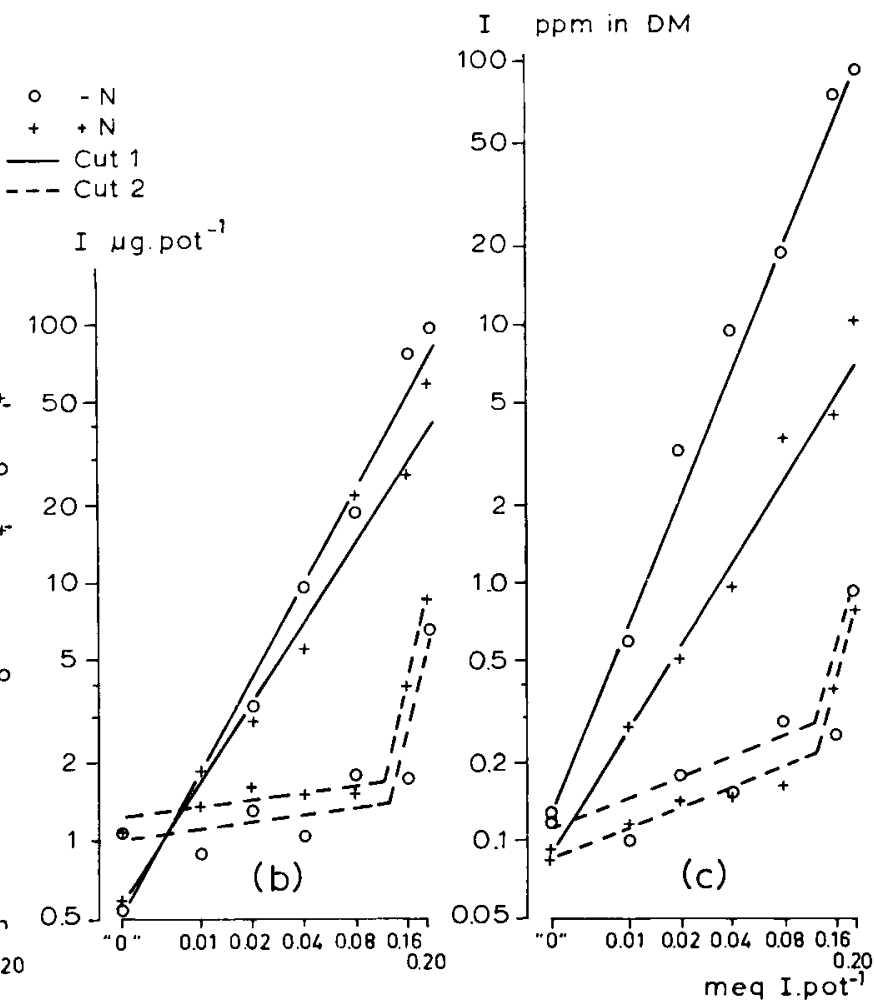

Fig. 1. DM yield (a), iodine uptake per pot (b), and iodine concentration in DM (c) of Lolium perenne at different iodine supply in the pot experiment.

generally does not vary to a great extent, though in Cut 2 they are somewhat less effective.

Residual effect in subsequent cuts. In the pot experiment Cut 2 shows a response similar to that in Field Exp. 3 in the cuts immediately following dressing, viz a very small effect on iodine concentration in the plant at the lower iodine doses. A significant residual effect is only present at the one or two higher iodine levels.

In Field Exp. 1 and 2 only two iodine levels have been applied. They show the residual effect in subsequent cuts is small compared to the main effect (Fig. 3, Table 1). In Cut 1 of Exp. 1 application of iodine results in a 40 -fold increase in iodine uptake, while in later cuts uptake is only increased 1.5 to 3 times. In Exp. 2 these figures are 17 and 2.5 times, respectively.

\section{Efficiency of iodine dressings}

The efficiency of a dressing is expressed as a percentage of the dose that is accumulated in the harvested herbage (in excess to that in the control). Data on the efficiency 

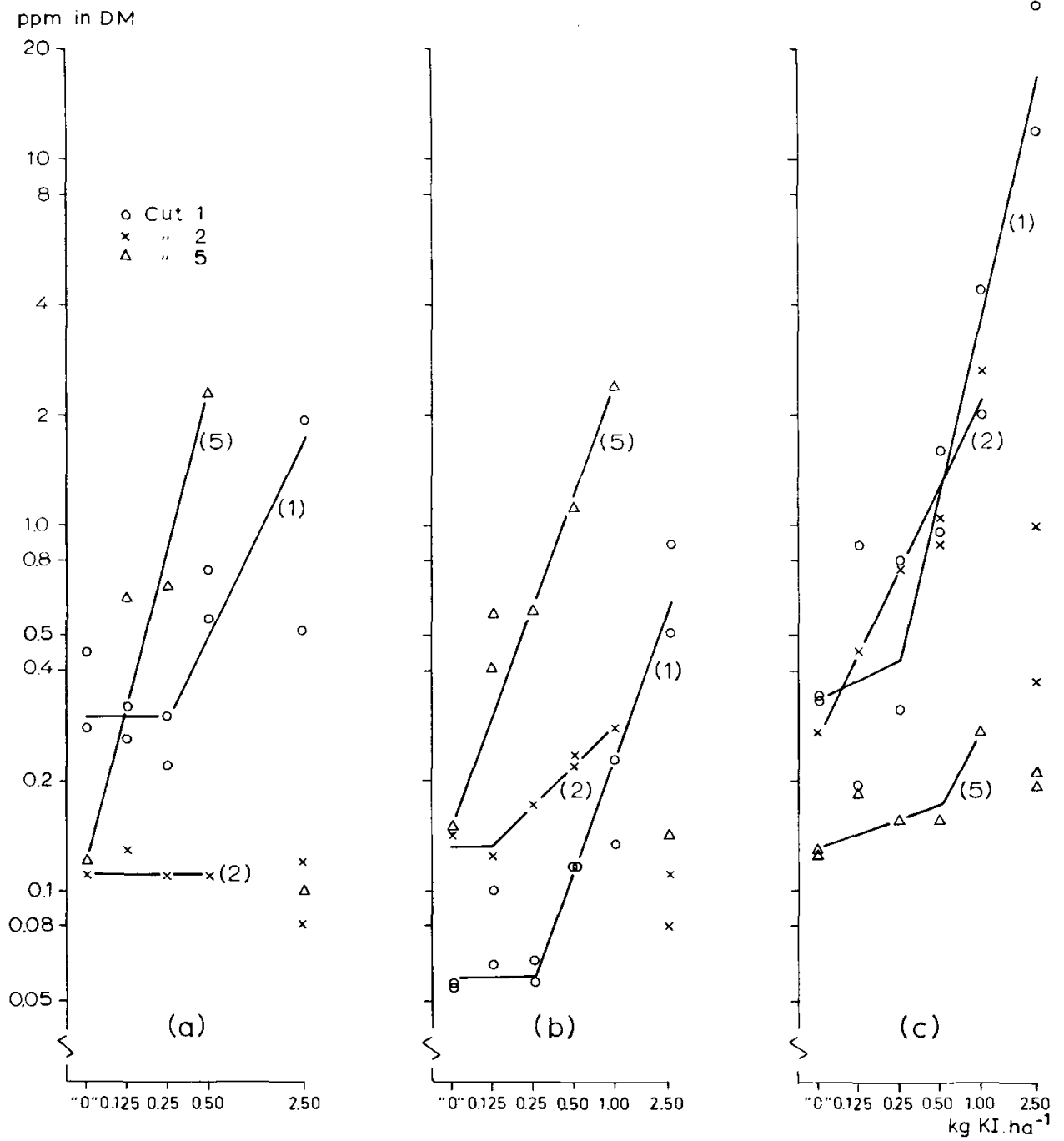

Fig. 2. Herbage iodine concentration $(\mathrm{mg} / \mathrm{kg} \mathrm{DM})$ in Field Exp. 3 with split dressings of iodine

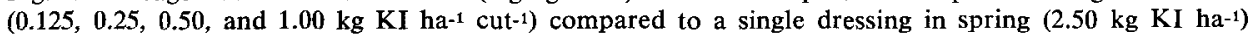
on sandy soil (a), river clay (b), and peat soil (c).

of iodine dressings in the various experiments are given in Table 2.

Though efficiency is low in all experiments, there are large differences. Efficiency is significantly higher at high iodine dressings than at the lower ones, while the residual effect in later cuts is small compared to the main effect in the dressed cuts. In Exp. 3 efficiency of iodine dressing is higher on peat soil than on sand or river clay; this is most pronounced at the high supply level. On the same soil type efficiency varies considerably, presumably due to soil and weather conditions. 


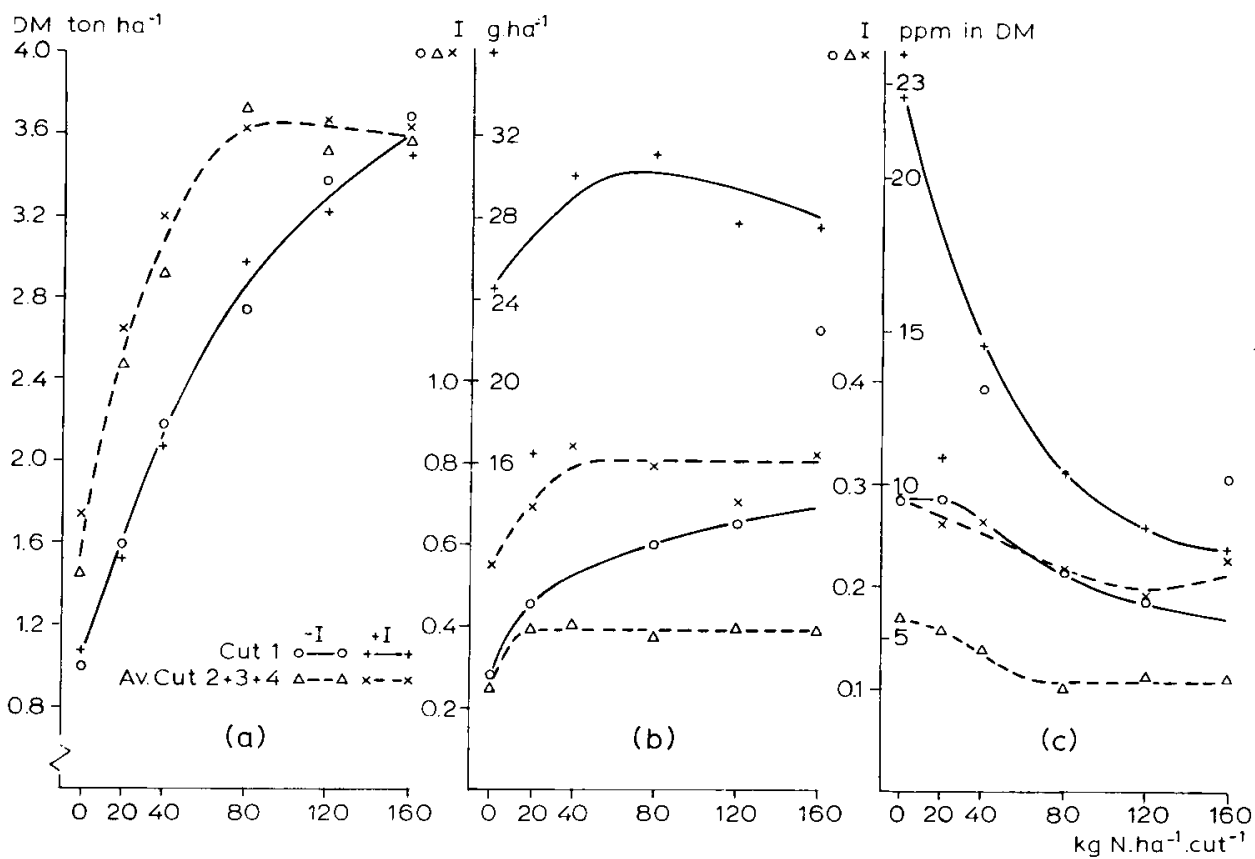

Fig. 3. DM yield (a), iodine uptake (b), and iodine concentration in herbage DM (c) at different $N$ supply in Field Exp. 1. Note that in (b) and (c) ordinate scale is different for treatment $+I$ in Cut 1.

Table 1. Effect of various fertilizers on iodine $(\mathrm{mg} / \mathrm{kg} \mathrm{DM})$ in herbage with $(+\mathrm{I})$ and without iodine dressing (-I). All plots received $80 \mathrm{~kg} \mathrm{~N}$ per ha per cut; $\mathrm{N}$ was applied as ammonium nitrate limestone, except for plots with a different $N$ source $(5,6,8)$.

\begin{tabular}{|c|c|c|c|c|c|c|c|c|c|c|c|}
\hline \multirow[t]{4}{*}{ No } & \multirow[t]{4}{*}{ Fertilizer } & \multicolumn{6}{|c|}{ Fertilizer constituents $\mathrm{kg} / \mathrm{ha}$} & \multirow{2}{*}{\multicolumn{4}{|c|}{$\begin{array}{l}\text { I in herbage DM } \\
(\mathrm{mg} / \mathrm{kg})^{2}\end{array}$}} \\
\hline & & \multirow{3}{*}{ total } & \multicolumn{2}{|c|}{$\mathrm{P}_{2} \mathrm{O}_{5} \mathrm{~K}_{2} \mathrm{O}$} & \multirow{3}{*}{ anc1 } & \multirow{3}{*}{$S$} & \multirow{3}{*}{$\mathrm{Cl}$} & & & & \\
\hline & & & & & & & & Cut 1 & & Cut 2 & \\
\hline & & & & & & & & -I & $+\mathbf{I}$ & $-I$ & $+\mathrm{I}$ \\
\hline 1. & Limestone & 2750 & & & 1100 & & & 0.07 & 1.32 & 0.09 & 0.17 \\
\hline 2. & Kieserite & 315 & & & & 65 & & 0.09 & 1.48 & 0.06 & 0.22 \\
\hline 3. & Superphosphate & 353 & 60 & & & 65 & & 0.07 & 1.45 & 0.11 & 0.20 \\
\hline 4. & Basic slag & 375 & 60 & & 112 & & & 0.08 & 1.30 & 0.07 & 0.20 \\
\hline 5. & Chilean (sodium) nitrate & 516 & & & 103 & & & 0.07 & 1.83 & 0.06 & 0.23 \\
\hline 6. & Calcium nitrate & 516 & & & 83 & & & 0.09 & 1.32 & 0.10 & 0.21 \\
\hline 7. & Ammonium nitrate limestone & 348 & & & 0 & & & (0.11) & 1.19 & 0.06 & 0.21 \\
\hline 8. & Ammonium sulphate & 381 & & & -57 & 91 & & 0.07 & 1.44 & 0.10 & $(0.41)$ \\
\hline 9. & Potassium sulphate & 375 & & 180 & & 65 & & 0.08 & 2.00 & 0.06 & 0.20 \\
\hline 10. & Potassium salt (chloride) $40 \%$ & 450 & & 180 & & & 227 & 0.11 & $(1.06)$ & 0.10 & 0.16 \\
\hline 11. & Potassium salt $20 \%$ & 900 & & 180 & & & 441 & 0.07 & 1.25 & 0.09 & 0.17 \\
\hline 12. & Treatments $3+7+10$ & 1151 & 60 & 180 & & 65 & 227 & 0.08 & 1.32 & 0.09 & 0.17 \\
\hline
\end{tabular}

1 anc $=$ acid-neutralizing constituents, expressed as $\mathrm{CaO}$.

2 Figures in parentheses indicate large differences between replicates. 


\section{FACTORS AFFECTING HERBAGE IODINE CONTENT}

Table 2. Efficiency of iodine applications in dressed and in later cuts.

\begin{tabular}{llll}
\hline Experiment & Iodine dressing & \multicolumn{2}{l}{$\%$ return in } \\
\cline { 3 - 4 } & & dressed cut & later cuts \\
Pot experiment & $0.08 \mathrm{meq} \mathrm{I} / \mathrm{pot}$ & 2.0 & 0.00 \\
& $0.20 \mathrm{meq} \mathrm{I} /$ pot & 3.5 & 0.02 \\
Field Exp. 1 & $2.68 \mathrm{~kg} \mathrm{KI} / \mathrm{ha}$ & 1.25 & 0.02 \\
Field Exp. 2 & $2.50 \mathrm{~kg} \mathrm{KI} / \mathrm{ha}$ & 0.17 & 0.02 \\
Field Exp. 3 & & & \\
sandy soil & $0.25 \mathrm{~kg} \mathrm{KI} / \mathrm{ha}$ & 0.00 & - \\
river clay & $2.50 \mathrm{~kg} \mathrm{KI} / \mathrm{ha}$ & 0.20 & 0.00 \\
peat & $0.25 \mathrm{~kg} \mathrm{KI} / \mathrm{ha}$ & 0.03 & - \\
& $2.50 \mathrm{~kg} \mathrm{KI} / \mathrm{ha}$ & 0.11 & 0.00 \\
& $0.25 \mathrm{~kg} \mathrm{KI} / \mathrm{ha}$ & 0.05 & - \\
\hline
\end{tabular}

$-=$ no data.

Table 3. Species and varietal differences in iodine content (mg/kg DM) of grasses and clovers in a variety testing experiment, average of 2 cuts in 1969.

Species and description of variety Iodine $(\mathrm{mg} / \mathrm{kg} \mathrm{DM})$

Trifolium repens (white clover), pasture type, moderately early $\quad \mathbf{0 . 1 7}$ pasture type, moderately late $\quad 0.15$ cultivated type, moderately early $\quad 0.18$ cultivated type, moderately late $\quad 0.16$

Dactylis glomerata (cocksfoot), 1 $2 \quad 0.12$ small-leafy $\quad 0.11$

Agrostis tenuis (common bent-grass)

0.11

Cynosurus cristatus (crested dog's-tail) $\quad \mathbf{0 . 1 0}$

Festuca arundinacea (tall fescue) $\quad 0.09$

$\begin{array}{ll}\text { Poa trivialis (rough-stalked meadowgrass) } & 0.09\end{array}$

$\begin{array}{ll}\text { Phleum pratense (timothy), hay type } & 0.11\end{array}$

intermediate type $\quad 0.07$

pasture type 0.08

$\begin{array}{ll}\text { Agrostis alba (white bent) } & 0.08\end{array}$

Poa pratense (smooth-stalked meadowgrass), $1 \quad 0.08$

Festuca protensis (meadow fescue), hay type 20.08

pasture type 0.08

Lolium perenne (perennial ryegrass), early hay type $1 \quad 0.07$

early hay type 2

late hay type 1

late hay type 2

pasture type 1

pasture type $2 \quad 0.08$

Lolium multiflorum (Italian ryegrass), $1 \quad 0.07$

20.07

$\begin{array}{ll}\text { Arrhenatherum elatius (tall oat-grass) } & 0.07\end{array}$

$\begin{array}{ll}\text { Festuca rubra (red fescue) } & 0.06\end{array}$ 


\section{Effect of nitrogen dressing on iodine concentration and uptake}

In the pot experiment iodine uptake per pot is not significantly different between $\mathrm{N}$ treatments, though at the higher iodine supply levels there is a tendency of iodine uptake per pot in Cut 1 being somewhat higher in the $-\mathrm{N}$ series, while iodine uptake in Cut 2 being slightly higher in the $+\mathrm{N}$ series (Fig. 1b). Because of large differences in $\mathrm{DM}$ production induced by the $\mathrm{N}$ supply, the iodine concentration in the harvested plant material is significantly lower in the $+\mathrm{N}$ series; this is most pronounced at the higher iodine levels in Cut 1 (Fig. 1c).

In the -I treatments of Field Exp. 1 iodine uptake per ha in Cut 1 increases with increasing $\mathbf{N}$ dressing, especially at the lower $\mathbf{N}$ levels (Fig. 3b). Since DM production increases with increasing $\mathrm{N}$ level, the iodine concentration in the herbage DM, although constant from 0 to $20 \mathrm{~kg} \mathrm{~N}$ per ha, decreases at the higher $\mathrm{N}$ levels to approximately $50 \%$ of the initial level (Fig. 3c).

In the $+I$ treatments iodine uptake per ha by Cut 1 increases only from 0 to $20 \mathrm{~kg}$ $\mathrm{N}$ per ha, and relatively less than in the - I treatments. At higher $\mathrm{N}$ application it remains constant or decreases slightly. As a consequence iodine concentration in herbage DM drops considerably with increasing $\mathrm{N}$ level, viz from $1.7 \mathrm{mg} / \mathrm{kg}$ at $0 \mathrm{~N}$ to $0.6 \mathrm{mg} / \mathrm{kg}$ at $160 \mathrm{~kg} \mathrm{~N}$.

Since the results of Cuts 2, 3 and 4 are similar, these have been averaged. In these cuts iodine uptake per ha increases only from 0 to $20 \mathrm{~kg} \mathrm{~N}$ at the low iodine level and from 0 to $40 \mathrm{~kg} \mathrm{~N}$ at the high iodine level. At higher $\mathrm{N}$ levels it remains constant. Since $\mathrm{N}$ dressings higher than $80 \mathrm{~kg} \mathrm{~N}$ per ha per cut do not give higher DM yields, iodine concentration in the herbage DM decreases with increasing $\mathrm{N}$ levels up to $80 \mathrm{~kg}$ $\mathrm{N}$, and remains almost constant at higher $\mathrm{N}$ levels (Fig. 3c). Thus, the decrease in iodine concentration in the herbage DM is greatest at the higher $\mathrm{N}$ levels in Cut 1 and at the lower $\mathrm{N}$ levels in later cuts.

\section{Effect of fertilizer type on iodine concentration in herbage}

Table 1 shows the small inconsistent effects of different types of $\mathrm{N}, \mathrm{P}$ and $\mathrm{K}$ fertilizers, at the same time supplying different quantities of $\mathrm{Ca}, \mathrm{S}$ and $\mathrm{Cl}$, on iodine concentration in the herbage. The same applies to dressings with limestone or kieserite.

\section{Species and varietal differences in iodine concentration}

Average iodine concentration in the different species and varieties of legumes and grasses of the variety testing experiment are presented in Table 3, arranged in the order of decreasing content of the species. On the average high iodine concentrations accur in white clover, cocksfoot and common bent-grass, lowest concentrations in red fescue, tall oat grass, Italian ryegrass and perennial ryegrass. Within species there are no systematic differences between early (stalky) and late-heading and late-flowering (leafy) varieties. Differences between varieties of one species are usually small compared with differences between (grass) species.

The grasses of this experiment have been subdivided into good quality grasses, medium-value grasses and inferior grasses according to Kruyne \& de Vries (1963) (Table 4). Iodine concentration in the white clovers is more than twice that in the good grasses. Concentration in the good grasses is also lower than in the mediumvalue grasses. In the inferior grasses both low and high iodine concentration occur. 
Table 4. Iodine content (mg/ $\mathrm{kg}$ in DM) of legumes, good, medium and inferior grasses in a variety testing experiment.

Iodine $(\mathrm{mg} / \mathrm{kg} \mathrm{DM})$

$\begin{array}{ll}\text { Legumes } & \\ \text { Trifolium repens } & 0.17 \\ \text { Good grasses } & \\ \text { Lolium perenne } & 0.07 \\ \text { Festuca pratensis } & 0.08 \\ \text { Phleum pratense } & 0.09 \\ \text { Poa pratense } & 0.08 \\ \text { Poa trivialis } & 0.09 \\ \text { Lolium multiflorum } & 0.07 \\ \text { Arrhenatherum elatius } & 0.07 \\ \text { Medium-value grasses } & \\ \text { Cynosurus cristatus } & 0.10 \\ \text { Dactylis glomerata } & 0.12 \\ \text { Inferior grasses } & \\ \text { Agrostis tenuis } & 0.11 \\ \text { Agrostis alba } & 0.08 \\ \text { Festuca arundinacea } & 0.09 \\ \text { Festuca rubra } & 0.06\end{array}$

Table 5 presents iodine concentrations in grasses and herbs from mixed vegetation, sampled in different localities, in the order of increasing iodine concentrations. As a group, grasses are several times poorer in iodine than herbs (dicotyledons). Of the latter legumes, plantain, ribworth and sorrel are poorest, white dead-nettle, dandelion, silverweed, ground ivy and germander speedweel are richest in iodine. Broad-leaved dock, cow parsnip and mouse-ear chickweed have intermediate iodine concentrations.

Table 5. Iodine content ( $\mathrm{mg} / \mathrm{kg} \mathrm{DM}$ ) of grasses and herbs mixed vegetations of different locations and in a iodine-dressed and a non-dressed field.

\begin{tabular}{|c|c|c|c|c|c|}
\hline \multirow[t]{2}{*}{ Species } & \multicolumn{5}{|c|}{ Iodine $(\mathrm{mg} / \mathrm{kg} \mathrm{DM})$ at location } \\
\hline & 1 & 2 & 3 & $4(-I)$ & $4(+1)$ \\
\hline Holcus lanatus (Yorkshire fog) & & & 0.02 & & \\
\hline Gramineae (mixed grasses) & 0.03 & 0.04 & 0.03 & 0.32 & 24.0 \\
\hline Trifolium pratense (red clover) & 0.04 & 0.06 & & & \\
\hline Trifolium repens (white clover) & 0.06 & & 0.06 & & \\
\hline Medicago lupulina (black medic) & 0.06 & & & & \\
\hline Plantago major (great plantain) & 0.03 & 0.09 & 0.04 & & \\
\hline Plantago lanceolata (ribworth) & 0.04 & 0.06 & 0.07 & & \\
\hline Rumex acetosa (sorrel) & 0.06 & 0.03 & 0.08 & & \\
\hline Rumex obtusifolius (broad-leaved dock) & 0.11 & 0.08 & & & \\
\hline Heracleum sphondilium (cow parsnip) & & 0.08 & & & \\
\hline Cerastium holosteoides (mouse-ear chickweed) & 0.09 & 0.09 & & & \\
\hline Veronica chamaedrys (germander speedweel) & & 0.10 & & & \\
\hline Glechoma hederacea (ground ivy) & & 0.10 & & & \\
\hline Potentilla anserina (silverweed) & & 0.11 & & & \\
\hline Taraxacum officinale (common dandelion) & 0.17 & 0.11 & 0.10 & 2.56 & 311 \\
\hline Lamium album (white dead-nettle) & & 0.18 & & & \\
\hline
\end{tabular}




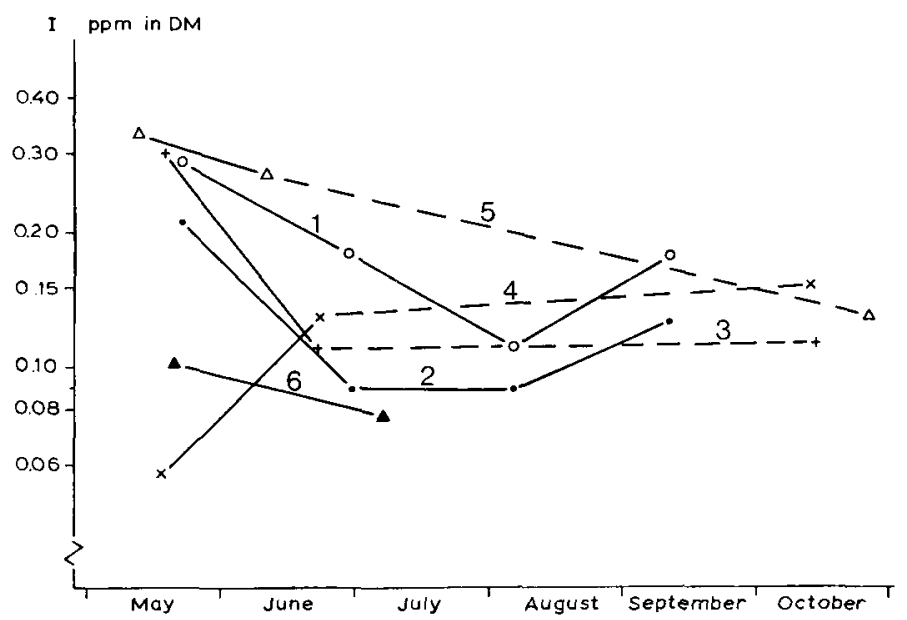

Fig. 4. Seasonal variation in herbage iodine content (mg/kg DM) in Field Exp. 1-20 N (1), 1-80 N (2), 3-sandy soil (3), 3-river clay (4), 3-peat soil (5), and 4 (6). Dates refer to harvest dates.

However, the order may differ somewhat between localities, e.g. for great plantain and sorrel from Location 2. It should be noticed that relative to grass dandelion utilizes iodine better at a high iodine level than at a low one: ratio of iodine concentration in dandelion to that in grass at high and low iodine level being $13: 1$ and $8: 1$, respectively.

\section{Effect of season}

Seasonal effects on herbage iodine concentration are presented in Fig. 4. In all but one of the fields iodine concentration is highest in Cut 1. It decreases in the summer cuts, and rises slightly in the autumn, in the 2 fields from which all cuts have been analysed.

\section{Discussion}

Iodine is not considered as essential for plant growth. Its presence in herbage plants is required by the grazing animal although the required minimum or optimum concentration in the ration is poorly defined. The Committee on mineral nutrition (Anon., 1973) has estimated the iodine requirement of high-yielding milking cows at $0.6 \mathrm{mg}$ iodine $/ \mathrm{kg} \mathrm{DM}$ in the ration, with a tolerance of $0.4 \mathrm{mg} / \mathrm{kg}$ for short periods.

These levels were not met in most of the plots of the present work, which were not fertilized with iodine. Early goitre surveys in the Netherlands have indicated that the lowest iodine supply is on sandy soils and river clay, the latter originating from parent material poor in iodine from the Alpine region. Reith (1933) accordingly found highest total iodine contents in soils of the younger marine clay polders and in peat soils, and lowest contents in sandy soils and in river clays.

Compared with earlier data iodine levels in herbage in the Netherlands have de- 
creased. Lehr (1961) found iodine concentrations in herbage ranging from 0.20 to 0.65 $\mathrm{mg} / \mathrm{kg} \mathrm{DM}$ on a number of sandy soils, while we found on the same soil type concentrations ranging from 0.04 to $0.40 \mathrm{mg} / \mathrm{kg}$. The main factor involved seems to be the considerably increased use of nitrogen fertilizer. The direct effect of nitrogen dressing on herbage iodine concentration is demonstrated in Field Exp. 1. In practice high $\mathbf{N}$ dressings are applied to the first cut; Fig. $3 \mathrm{c}$ shows that the decrease in iodine concentration of Cut 1 is largest at these high $\mathbf{N}$ dressings. Moderate $\mathrm{N}$ dressings are applied to later cuts and result again in a proportionally large depression of iodine concentration.

Secondary effects of increased use of nitrogen fertilizers are the decrease in legumes and herbs rich in iodine, and the stimulation of good grasses poor in iodine, both effects resulting in lower iodine concentration in herbage DM. Thus, intensification of pasture use has decreased the iodine supply to grazing animals considerably.

The present study confirms the literature data that dicotyledons are generally higher in iodine than the grasses. With respect to the differences between grass species there is agreement in some cases and not in other. Cocksfoot is highest of the grasses in the present results and in those of Alderman \& Jones (1967), while Yorkshire fog is low as in those of Johnson \& Butler (1957). In our study and in that of Alderman \& Jones, however, perennial ryegrass and white clover are comparatively much lower than in the New Zealand study. Butler \& Glenday (1962) demonstrated that the iodine level in plants is of a highly heritable character. Breeding for maximum crop yields of good grasses and clovers, and not being concerned with iodine concentration, may have caused the natural iodine concentration in the improved species to fall and may have conditioned the lower actual iodine concentrations in the herbage of all good grasses and clovers examined.

The seasonal effects on herbage iodine content are comparable to those found by Alderman \& Jones (1967) in Wales, but differ somewhat from the pattern found by Lehr (1961). It is not known whether the data of Lehr possibly refer to one particular year of abnormal external conditions.

One of the means to improve the iodine supply of grazing animals is to increase iodine concentration in forage by iodine dressings. However, the experiments show very low efficiency of such dressings, especially in later cuts (Table 2). Furthermore, on sandy soil and river clay low in iodine, the direct effect and the residual effects II later cuts are smaller than on peat richer in iodine. Thus, this method is ineffective under more critical conditions.

With regard to the very low residual effect of single dressings, split applications of lodine might be an alternative. However, split dressings were always less efficient than larger single dressings (Table 2) and this renders split iodine dressings (which e.g. could be applied in combination with $\mathrm{N}$ dressings) even less acceptable than single dressings, especially on soils low in iodine.

After iodine dressing a rapid loss or immobilization of iodine appears to occur in the soil. Only when applied in excess, plants wil absorb more iodine (Fig. 2). In later cuts, considerably less iodine is absorbed than in dressed cuts indicating a further immobilization or loss in time (Fig. 1, Table 2). For different years and parts of the season immobilization occurs mainly in dry periods on soils more susceptible to drought. Seasonal fluctuations in herbage iodine content will be, at least partly, due to this factor (Fig. 4).

Some earlier publications (von Fellenberg et al., 1924; Scharrer \& Schwaibold, 1928) reported greater losses of iodine from soils of low $\mathrm{pH}$ and from mineral soils, where 
high contents of iron and manganese in oxydized forms may act as oxydation catalysts. Organic matter may reduce this loss to a considerable extent. This may explain to a great extent the variations in total iodine contents in soils described by Reith (1933). It is not clear in our experiments, however, in how far iodine from dressings was lost from the soil by oxydation and subsequent sublimation, or was immobilized due to incorporation into soil constituents. Anyhow, iodine dressings were inefficient in increasing iodine concentrations of herbage, especially on soils low in iodine.

Intensification of pasture use in several ways decreases the iodine supply to grazing animals, while higher animal production tends to increase the animal's requirement for the element. Since under these conditions increase of herbage iodine content is very inefficient, other means should be found to supply the animal. To day, administration of concentrates to grazing cattle is a normal practice in the Netherlands. It should be technically possible to include a higher supplementation of iodine in these concentrates.

\section{Acknowledgments}

The author is indebted to Ms Ir C. L. Harberts, Drs N. Vertregt and Mr O. C. Spoelstra for iodine analysis, to Ir $\mathrm{H}$. Vos for providing samples from variety testing experiments, to Ing. O. J. Hemkes for carrying out the field experiments, to $\mathrm{Mr} \mathrm{J}$. Randewijk for greenhouse assistance, and to Dr W. Dijkshoorn for critically reading the manuscript.

\section{References}

Alderman, G. \& D. I. H. Jones, 1967. The iodine content of pastures. J. Sci. Fd Agric. 18: 197-199. Anonymous 1973. Tracing and treating mineral disorders in dairy cattle. Prepared by the Committee on Mineral Nutrition. Pudoc, Wageningen.

Barker, S. B., M. J. Humphrey \& M. H. Soley, 1951. The clinical determination of protein-bound iodine. J. clin. Invest. 30: 55-62.

Binnerts, W. Tj., 1956. Het jodiumgehalte van melk. Meded. LandbHogesch. Wageningen 56-4.

Butler, G. W. \& J. M. Johnson, 1957. Factors influencing the iodine content of pasture herbage. Nature, Lond. 179: 216-217.

Butler, G. W. \& A. C. Glenday, 1962. Iodine content of pasture plants. II. Inheritance of leaf iodine content of perennial ryegrass (Lolium perenne L.). Aust. J. biol. Sci. 15: 183-187.

Fellenberg, Th. von, H. Geilinger \& K. Schweizer, 1924. Untersuchungen über das Vorkommen von Jod in der Natur. VIII. Ueber das Freiwerden elementaren Jods aus Erde. Biochem. Z. 152: $172-184$.

Foss, O. P.. L. V. Hankes \& D. D. van Slyke, 1960. A study of the alkaline ashing method for detel sitioni of protein-bound iodine in serum. Clin. chim. Acta 5: 301-326.

Johnson, J. M. \& G. W. Butler, 1957. Jodine content of pasture plants. I. Method of determination and preliminary investigation of species and strain differences. Physiol. Plant. 10: 100-111.

Kruyne, A. A. \& D. M. de Vries, 1963. Data concerning important herbage plants. Meded. Inst. biol. scheik. Onderz. LandbGew. 225.

Lehr, J. J., 1961. Over de jodiumvoorziening in Nederland van mens en dier. Voeding 22: 377-384.

Reith, J. F., 1933. Jodgehalte von niederländischen Böden in Zusammenhang mit einigen geologischen und landwirtschaftlichen Fragen. Z. PflErnähr. Düng. Bodenk. 31: 215-224.

Sandell, E. B. \& I. M. Kolthoff, 1937. Microdetermination of iodine by a catalytic method. Mikrochim. Acta 1: 9-25.

Scharrer, K. \& J. Schwaibold, 1928. Zur Kenntnis des Jods als biogenes Element. 17. Untersuchungen über das Jodabspaltungsvermögen der Böden. Biochem. Z. 200: 258-272. 